\title{
АНАЛІЗ ШЛЯХІВ ПІДВИЩЕННЯ ТЕМПЕРАТУРИ ГАЗІВ ПЕРЕД ТУРБННОЮ СУЧАСНИХ ГАЗОТУРБІННИХ ДВИГУНІВ ЛІТАКІВ
}

В статті проведений аналіз особливостей роботи газової турбіни, як основного елемента газотурбінного двигуна (ГТД), в умовах дї̈ високих робочих температур та тиску, розглянуто статистику характерних відмов і несправностей газових турбін, які знижують надійність роботи двигунів, та запропоновані альтернативні шляхи їх подолання. Розглянуто иляхи підвищення температури газів перед турбіною сучасних ГТД та деякі системи охолодження соплових апаратів та робочих лопаток турбін. Проаналізовані напрямки підвищення параметрів робочого прочесу газових турбін з метою забезпечення безвідмовної роботи авіаційної техніки в процесі експлуатації.

Ключові слова: експлуатація, технологія прототипірування, монокристалічне виготовлення лопаток, термодифузійний віджиг деталей, транспіраиійне охолодження.

\section{Вступ}

Постановка задачі. Сучасні методи і засоби підвищення ефективності складних технічних об'єктів, як показує досвід створення авіаційних газотурбінних двигунів п'ятого покоління, обумовлюються необхідністю формування нової технології, яка б покращувала газодинамічні параметри роботи двигунів [1-2].

Розширення умов бойового використання літальних апаратів (ЛА) пов'язане $з$ проблемою створення двигунів для літаків 5-го покоління, які б забезпечували можливість виконання польотів на надзвукових швидкостях 3 використанням максимального режиму його роботи . У зв'язку з цим підвищується роль двигуна в забезпеченні безпеки польотів, що обумовлено вимогами до боєготовності і бойової живучості, надійності і ресурсу елементів, які підлягають високим циклічним навантаженням. У свою чергу це призводить до ускладнення конструкції і підвищення іiї вартості $[1 ; 4]$.

Для забезпечення безпеки польотів літака на максимальному режимі необхідно підвищувати тягу двигуна за рахунок підвищення температури газів, збільшення степеня стиснення повітря, зменшення витрати повітря на охолодження, зменшення питомої маси і питомої витрати палива $\left(m_{n u m}, C_{n u m}\right)$ двигуна. Необхідно створювати і використовувати нові авіаційні матеріли та технології, які б забезпечували значне підвищення надійності найбільш важливих елементів конструкції.

До таких напрямків технологій в процесі виготовлення елементів конструкції в гарячій частині, а саме для соплових апаратів (CA), робочих лопаток (РЛ) турбіни відносять: виготовлення заготовок на основі швидкого прототипірування, монокристалічне виготовлення лопаток, захист поверхонь від газо- вої корозії, окиснення і взаємодії високих робочих температур за рахунок застосування сучасних методів нанесення захисних покриттів, доцільного вибору системи охолодження турбіни.

Аналіз останніх досліджень і публікацій. Питанням вирішення проблеми підвищення температури газів перед турбіною та удосконалення проектування системи охолодження робочих коліс турбіни ГТД серед вітчизняних і світових експертів приділяли увагу Ножницкий Ю.А. [4], Магеррамова Л.А. [6], Богуслаев А.В. [1-3], Муравченко Ф.М. [1], Олейник А.А. [3], Васильев Б.Е. [5], Викулин А.В. [8], Ярославцев Н.Л. [8], Барський І.А. [10], Каблов Е.Н. [12] і інші. Отримані ними результати дозволили розробити методи розрахунку і оцінки ефективності процесів газодинаміки, теплообміну і міцності охолоджуємих газових турбін при дії високих температур і тиску робочого тіла. Дана стаття направлена на пошук шляхів вирішення питання підвищення температури газів перед турбіною, як основного елемента ГТД для забезпечення ефективності використання і підтримки високої боєготовності авіаційної техніки в процесі експлуатації.

Мета статті: аналіз ефективності систем охолодження газових турбін при підвищенні температури газів перед турбіною з покращенням основних параметрів роботи двигуна.

\section{Виклад основного матеріалу}

Безвідмовна робота лопаток турбіни значною мірою залежить від роботи всіх елементів гарячої частини двигуна. Підвищення робочих параметрів в турбіні ГТД супроводжується інтенсифікацією процесів пошкодження робочих лопаток під дією статичних, динамічних і вібраційних навантажень, корозійного і ерозійного впливу. Дія цих факторів спри- 
яє появі в матеріалі широких областей деформації. Безпосередньо впливу газового потоку зазнають також деякі роторні і статорні деталі турбіни: корпус, обід дисків, лабіринтні ущільнення і менш навантажені елементи.

На робочі лопатки турбіни діють, окрім змінних вібронапружень, також фактори, що призводять до накопичення ушкоджень: змінні термічні напруження, повторні статичні напруження при високих температурах, перегріви робочих лопаток (наприклад, місцеві - через нерівномірність поля температур як по колу, так і по радіусу). При інтенсивних коливаннях лопаток втовлюмальним руйнуванням та розтріскуванням можуть піддаватись і замки лопаток. Згідно [2] втомні руйнування лопаток турбін складають до 33\%, руйнування від малоциклової втоми - близько 9\%, руйнування від поєднання малоциклової втоми, вібраційних напружень - близько $42 \%$ і руйнування, пов'язані з вичерпанням тривалої міцності - 16\%. Останні різко знижують опір тривалому статичному навантаженню, що може призвести до обриву лопаток із характерними слідами пластичної деформації. Перегріви соплових лопаток викликаються, зазвичай, кільцевою нерівномірністю температурного поля. 3 урахуванням вище наведеного аналізу, для забезпечення надійності роботи двигуна середня температура на радіусі лопатки не повинна перевищувати $900 \ldots 1000^{\circ} \mathrm{C}$, а максимальна температура $1100^{\circ} \mathrm{C}[3]$.

Тріщини та руйнування дисків турбін відносяться до найбільш небезпечних видів відмов, бо при обриві частини диску руйнування в багатьох випадках не локалізуються в межах корпусу двигуна. Частіше, в процесі розвитку тріщин, в диску виникає збільшення рівня загальних вібрацій двигуна (з роторною частотою), що може служити діагностичною ознакою цієї відмови та дозволяє запобігти руйнуванню диска при своєчасному вимкненні двигуна. При виявленні тріщини в диску двигун достроково знімається з експлуатації.

Одним 3 найбільш розповсюджених дефектів дисків турбін є розтріскування поверхні пазів замків ялинкового типу. Причиною виникнення тріщин частіше за все $\epsilon$ термічна втомлюваність, що виникає в матеріалі при повторних термічних навантаженнях в момент дроселювання двигуна, запуску та зупинки ГТД.

Небезпечні руйнування дисків можуть бути наслідком статичного перевантаження (наприклад, перегріву внаслідок перевищення обмежень частоти обертання ротору). Диски, що виготовлені з порушенням технологічного процесу, внаслідок тривалої роботи при високих температурах втрачають пластичність, що може призвести до їх крихкого руйнування навіть при відносно невеликому збільшенні статичної напруженості [1].
Для забезпечення ефективності роботи елементів турбіни на протязі назначеного ресурсу для ГТД 4++ та 5-го покоління застосовують деякі конструктивно-технологічні заходи:

- застосування спеціальних жаростійких, жароміцних і корозійно стійких сплавів, які здатні протистояти сульфідно-оксидній корозіі;

- виготовлення лопаток методом направленої кристалізації або з монокристалів;

- покриття для підвищення жаростійкості матеріалу (наприклад, з окису алюмінію);

- металеві багатокомпонентні захисні покриття для підвищення корозійної жаростійкості матеріалу - наприклад, покриття 34 компонентів (нікель - хром - алюміній - ітрій);

- теплозахисні покриття з керамічних матеріалів, які мають низьку теплопровідність - для зниження теплового потоку в матеріалі лопатки;

- різні схеми повітряного охолодження [6].

Забезпечення високих температур стало можливим не тільки завдяки удосконаленню системи охолодження, а й застосуванню жароміцних і жаростійких матеріалів, підвищенню термічного КПД.

Однак розробка і застосування нових авіаційних матеріалів, підвищення їх характеристик значно відстає від темпу зростання температури газів в турбінах ГТД (рис. 1).

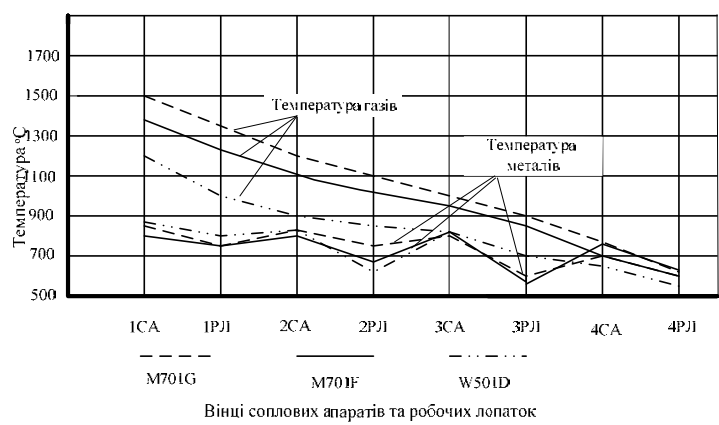

Рис. 1. Залежність температури газу перед турбіною від матеріалу

Джерело: розроблено авторами за даними [1, с. 18]

На графіку представлено, що температура лопатки залишилася незмінною не дивлячись на значне підвищення температури газів.

Від характеристик матеріалу, з якого виготовлено конструктивні елементи гарячої частини турбіни двигуна, залежить працездатність турбіни. Так, для зменшення маси турбіни намагаються підібрати матеріал для дисків з більш високою короткочасною i довготривалою міцністю. Однак зі збільшенням статичної міцності матеріалу його пластичність зменшується, що, в свою чергу, призводить до погіршення характеристик малоциклової втомленості і тріщиностійкості. В наш час, враховуючи тенденцію збільшення циклічного ресурсу, основними критері- 
ями вибору матеріалу для дисків поряд з міцністю $є$ малоциклова втомленість і опір росту тріщин. За кордоном використовуються гранульовані сплави IN100, RENE95, MERL76 (двигуни V2500, PW2000), які відносяться до сплавів 1-го покоління [7].

Розмір гранул для виготовлення дисків вітчизняних сплавів складає 50..140мкм. Крім цього, в розвинутих країнах, таких як Китай, Франція, США після гарячого ізостатичного пресування добавляють операцію деформування, що дозволяє отримати більш рівномірну бездефектну структуру сплаву і підвищує чутливість ультразвукового контролю [3].

Матеріал для соплових апаратів, робочих лопаток, дисків, валів повинен мати високу міцність, добре оброблятися і мати задовільну корозійну стійкість. Для виготовлення турбінних валів застосовуються сплави 40ХНМА, ЭИ961Ш, ЭП517. Матеріал лопаток газових турбін повинен мати малу чутливість до концентрації напружень, протистояти термічній втомленості, гарно оброблятися, мати доступну ціну.

Великий внесок для забезпечення надійності роботи турбіни і оптимізації робочих параметрів був виправданий застосуванням в практиці виготовленням сплавів 3 направленою кристалізацією і монокристалічних сплавів. Виготовленням монокристалічних сплавів займалася фірма Pratt\&Whitney, яка розробила вже понад 3 покоління монокристалічних сплавів (PWA1480, PWA1484, PWA1487), а компанія GE Aircraft Engines використовує монокристалічні сплави Rene N5 i Rene N6 (рис. 2).

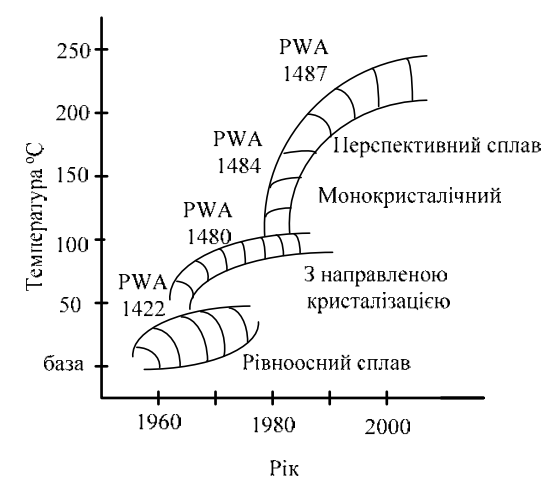

Рис. 2. Температурний рівень роботоздатності жароміцних сплавів

Джерело: розроблено авторами за даними [10, с. 45]

Головна ідея сплавів 3 направленою кристалізацією полягає в ліквідації проміжку між зернами, перпендикулярних напрямку відцентрових сил. Тобто виключення можливості для повзучості і руйнуванню на границях зерен.

Робочі лопатки і соплові апарати мають свою технологію і методи виготовлення. Так, лопатки отримані методом направленої кристалізації, мають збільшену в 2,5 рази міцність, збільшену в 6 разів стійкість до термічної втоми і збільшену в 2 рази стійкість до окиснення і корозії. Для монокристалічної лопатки міцність і стійкість до термічної втоми покращуються в 9 разів, а стійкість до окису і корозії в 3,5 рази. На відміну від сплавів 3 направленою кристалізацією, монокристалічна деталь не має границі зерен, тому має більш оптимальні характеристики міцності. Жароміцні матеріали є одними з прогресивних двигунів в забезпечення працездатності турбіни при збільшення температури газу. Перевага монокристалічного лиття реалізується за рахунок підвищення цін на матеріали і збільшення маси лопатки приблизно на 20\%.

Беручи до уваги швидкий темп розвитку виробництва нової авіаційної техніки, виникає потреба вдосконалення технологій виготовлення виробів АТ. 3 метою скорочення часу на проектування, зниження затрат на виготовлення, інженери використовують технологію швидкого прототипірування і центр обіжного лиття лопаток, що представляє собою обробку робочих поверхонь хвостовика і бандажних полок методом глибокого шліфування, захист від газової корозії, окислення і дії високих температур шляхом нанесення металічних і термозахисних покриттів.

Одним із способів підвищення точності виготовлення лопаток турбіни є застосування системи швидкого прототипірування, реалізованої в LOMустановках 1015/2030 (Laminated Object Manufacturing) фірми HELISYS (США), яка дозволяє отримати фізичну копію комп'ютерної моделі шляхом вирощування зі слоїв ламінованого паперу або полімерної смужки, послідовно розкриваючи їх світлом лазера 3 послідуючим термопресуванням. Виготовлення заготовок лопаток литтям в оболочкові форми можливо шляхом поєднання технології швидкого прототипірування і PROTOMIX (система вакуумного лиття). За допомогою неї виготовляють пластмасову модель лопатки, яка є більш міцною і легше обробляється при отриманні епоксидопласних форм порівняно з LOM - моделлю [3].

3 метою забезпечення високого рівня якості параметрів поверхневого шару металу використовують технологію глибокого шліфування, яка дозволяє за одну установку лопатки зробити формообразування на хвостовику або бандажних полках, до яких при виготовленні лопаток турбіни висувають високі вимоги.

Термозахисні (керамічні) покриття забезпечують зменшення теплового потоку в деталях за рахунок зменшення теплопровідності захисного шару. Зменшення максимальної температури металу складає від 30 до $90^{\circ} \mathrm{C}$ (в залежності від товщини покриття, його властивостей і градієнта температур між газом і стінкою лопатки). 
Широке застосування захисних покриттів для лопаток турбіни високого тиску (ТВТ) почалося в 1990-х роках на високотемпературних двигунах, що мали значну тягу (PW4084, GE90). В Україні ці технології вперше були вивчені в Інституті електрозварки АН України ім. Е.О. Патона [2].

Завдяки цій технології зменшується швидкість теплового потоку від газу до поверхні лопаток, тим самим при однакових умовах знижується температура самої лопатки. Наприклад, при товщині термозахисних покриттів (ТЗП) $0.2-0.25 \mathrm{Mм}$ зниження температури лопатки складає приблизно 30-35К. Покриття пера лопатки спеціальними емалями на основі окису хрому, цирконію, кремній органічними або спеціальними кераміками знижують температуру металу лопатки на $110-120^{\circ} \mathrm{C}$ в порівнянні з незахищеною лопаткою. Причому аеродинамічні втрати в решітці лопаток з керамічним покриттям такі ж, як i в звичайних лопатках при однаковій відносній товщині вихідних кромкою [6].

На двигунах 4-го та 4+ покоління на статорних i роторних лопатках застосовуються ТЗП на основі кераміки $з$ низькою теплопровідністю із стабілізованого ітріем цирконія $\left(\mathrm{ZrO}_{2}-\mathrm{Y}_{2} \mathrm{O}_{3}\right)$. Даний вид покриття наноситься плазменим напиленням і відіграє роль теплового бар'єра, зменшуючи температуру металу лопатки на $20-50^{\circ} \mathrm{C}$. Але такий вид ТЗП має вид горизонтальних слоїв з односторонньою структурою і володіє недостатньо високою стійкістю до термічної витривалості в експлуатації - в покритті виникають мікротріщини і воно відокремлюється від лопатки. Інший вид ТЗП (склад ідентичний) має стовбчасту структуру, отриману випаровуванням під дією електричного світла 3 послідуючим осадженням на поверхню лопатки. Він має непогану стійкість до термічної втомленості і не закриває отвори плівкового охолодження при нанесенні. Вiдокремлення покриття може виникнути в разі окиснення захисних слоїв. Використання захисних покриттів істотно знижує витрату охолоджуючого повітря, збільшує ефективність їх застосування. Однак для використання такого виду ТЗП необхідне коштовне обладнання.

В наш час вже розроблені технологічні операції, застосування яких зменшує негативну дію покриттів. До них відносяться термодифузійний віджиг деталей 3 Нікель-Кадмієвим покриттям, який не знижує границю витривалості лопаток із корозійностійких сталей при нормальній температурі і сприяє збереженню його навіть після експлуатації деталей і при наявності на лопатках ерозійних пошкоджень.

Сучасна ефективна система охолодження є невід'ємною складовою частиною конструкції газової турбіни двигуна. В ТВТ охолоджуються всі лопатки ротора, корпус, диск. В турбіні низького тиску (ТНТ) охолоджуються - ротора, корпус і доволі час- то - робочі лопатки 1-ї ступені СА. Безперервне вдосконалення і ускладнення технології охолодження є обов'язковою умовою реалізації конкурентоспроможності конструкції турбіни - конструкції, в якій при збільшенні температури перед турбіною, витрата повітря на охолодження не втрачає виграшу в питомих параметрах двигуна, а ресурс деталей турбіни відповідає вимогам замовника [4].

В цілому необхідно відмітити, що удосконалення систем охолодження призводить до підвищення температури і збільшення кількості повітря, відбираємого на охолодження. Як правило, витрата охолоджуючого повітря на охолодження СА 1-ї ступені в сучасних ГТД орієнтовно складає 5-7\% від витрати повітря на вході в компресор, РЛ - 3,55,5\%. На охолодження торцевої поверхні СА 1-ї ступені відбирається 1,5-2,5\%, на охолодження бандажних полок РЛ 1-ї ступені або вставок над ними $-2-3 \%$.

Існує декілька шляхів зменшення витрати повітря на охолодження турбіни:

- формування оптимальної радіальної температури газу за КЗ;

- зменшення окружної нерівномірності температури за КЗ;

- застосування апарата закрутки повітря в напрямку оберту диску на вході в ротор ТВТ (при цьому знижується температура охолоджуючого повітря);

- попередне охолодження повітря в повітряноповітряному теплообміннику, встановленому в зовнішньому контурі ТРДД (така схема реалізована на двигунах Д-30Ф6 і АЛ-31Ф);

- зменшення втечі охолоджуючого повітря в проточну частину турбіни;

- створення системи автоматичного керування і управління радіальними зазорами;

- збільшення ефективності системі охолодження лопаток;

- зменшення витрати тиску охолоджуючого повітря при підводі до лопаток.

Для кількісної оцінки відносної ефективності системи охолодження використовують формулу:

$$
\theta=\left(T_{\Gamma}-T_{Л}\right) /\left(T_{\Gamma}-T_{\Pi}\right),
$$

де $\theta$ - відносна ефективність охолодження;

$T_{Л}$ - температура лопатки;

$T_{\Gamma}$ - температура газу;

$T_{\Pi}$ - температура охолоджуючого повітря.

Найбільш широко розповсюдженою системою охолодження сучасних турбін $є$ схема відкритого (3 випуском охолоджувача в проточну частину турбіни) повітряного охолодження. Для більш ефективної роботи двигуна в цілому, необхідно щоб турбіна 
мала незначну витрату охолоджуючого повітря, яке відбирається з проміжних ступенів компресора.

В ГТД застосовують такі системи охолодження елементів конструкції газових турбін (рис. 3):

- конвективне охолодження (поперечне, повздовжнє, поперечно-повздовжнє);

- пористе охолодження;

- комбіноване охолодження;

- рідинне охолодження (випаровуванням);

- охолодження рідкими металічними теплоносіями.

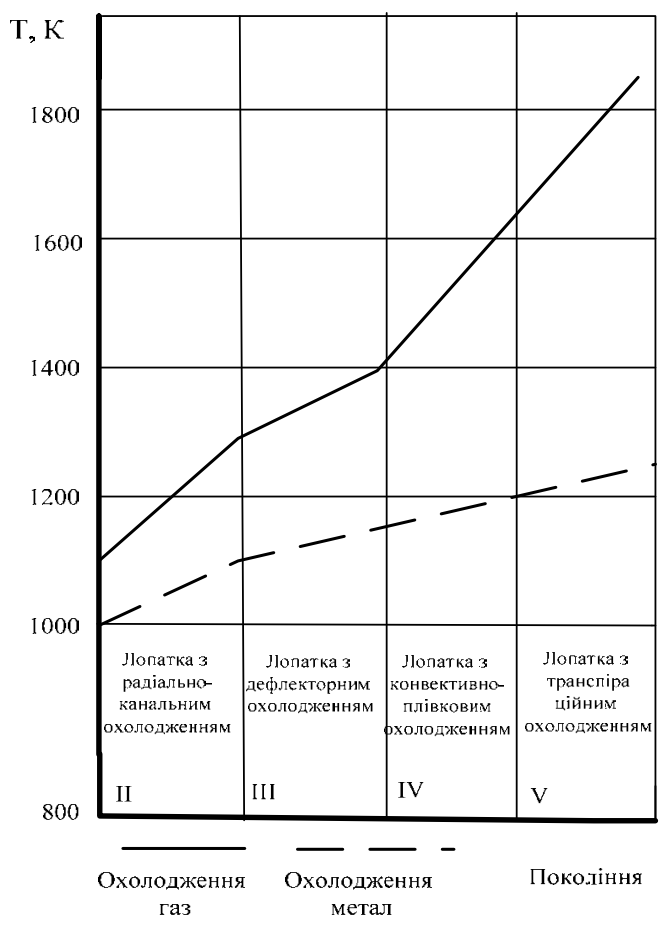

Рис. 3. Способи охолодження РЛ

при різних температурах в залежності від покоління Джерело: розроблено авторами за даними [3, с. 117]

Охолодження робочої лопатки відведенням тепла в диск застосовується до температур $T_{\Gamma}^{*}=$ 1 000-1 263К. При цьому температура лопатки в максимально нагрітому перерізі (приблизно на 2/3 довжини пера від кореня) на $140-160^{\circ} \mathrm{C}$ нижче температури газів перед сопловим апаратом за рахунок відведення тепла в диск температура кореневої третини пера на $80-150^{\circ} \mathrm{C}$ нижче, ніж була б у неохолоджуваної лопатки.

Такий спосіб сприяє підвищенню міцнісних властивостей матеріалу в небезпечному перерізі пера лопатки. При конвективному охолодженні охолоджуюче повітря надходить всередину пера лопатки через отвори в замку, проходить по охолоджуючим каналам, відбирає тепло від стінок лопатки i виходить в проточну частину турбіни. Такий спосіб охолодження в залежності від конструктивного виконання застосовується до $T_{\Gamma}^{*}=1400-1500 \mathrm{~K}$.
Одним із видів конвективного охолодження є циклонно-вихрове охолодження [8]. У лопатці виконується спеціальна матриця 3 нахиленими каналами і різкими поворотами потоку охолоджуючого повітря, що представлена на рис. 4.

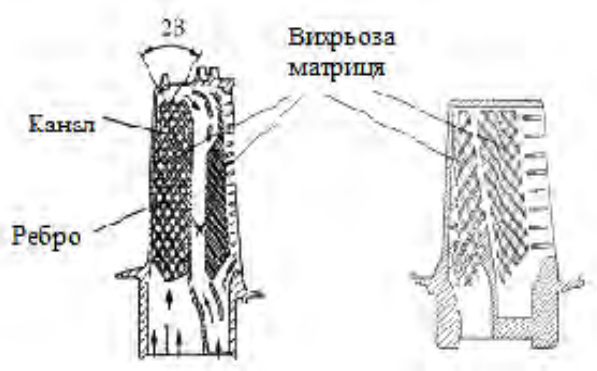

Рис. 4. Схема робочої лопатки 3 циклонно-вихрьовою матрицею Джерело: розроблено авторами за даними [2, с. 78].

Циклонно-вихрьове охолодження разом 3 монокристалічною лопаткою може застосовуватися при $T_{\Gamma}^{*}=1650-1700 К$, але при цьому виникає необхідність в охолоджуючому повітрі з підвищеним тиском для подолання великих гідравлічних втрат при проходженні повітря по внутрішнім каналам пера лопатки.

Пористе охолодження є більш перспективним при температурах $T_{\Gamma}^{*}$ більше 1 600-1 800К. Стінки лопаток виготовляються пористими, наприклад, методом порошкової металургії. Охолоджуюче повітря, рухаючись у внутрішніх каналах, спочатку відбирає тепло від стінок конвекцією, а потім після виходу через пори стінок на зовнішній профіль лопатки, виникає тонкий охолоджуючий шар біля поверхні профілю лопатки. Проміжним між конвективно-плівковим і пористим охолодженням є так зване транспіраційне охолодження. При такому способі охолодження стінки лопаток виконуються у 2 шари 3 великою кількістю маленьких нахилених отворів по всій поверхні профілю лопатки. Монокристалічні лопатки 3 транспіраційним охолодженням, виготовлені зі сплаву ЖС-47 (легованого ремнієм до $10 \%)$, здатні витримувати температуру $T_{\Gamma}^{*}=2000 \mathrm{~K}$ (рис. 5).

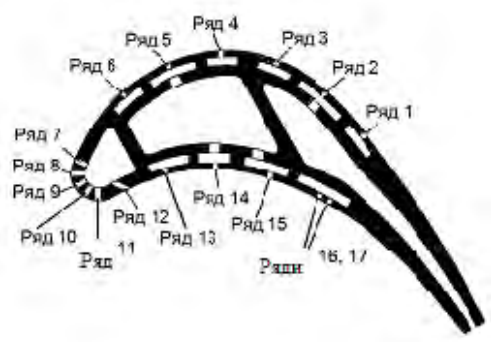

Рис. 5. Схема лопатка з транспіраційним охолодженням (технологія гнучких стержнів) Джерело: розроблено авторами за даними [8, с. 25] 
На сьогоднішній час можливості підвищення ефективності існуючих систем охолодження турбін ГТД практично вичерпані: відбір повітря від компресора на охолодження турбіни досягає максимального значення - $15-20 \%$, температура відбираємого повітря на охолодження перевищила $900 К$, коефіцієнт інтенсивності охолодження лопаток турбіни наближається до технічного максимуму 0,8 (пористе охолодження). У зв'язку з цим, з підвищенням температури за компресором, яке відбирається на охолодження елементів конструкції, виникає необхідність охолодження цього повітря. Тому необхідно встановлювати у 2-му контурі теплообмінників.

Запропоновані заходи дозволяють отримати підвищені показники температури газів перед і за турбіною, збільшити тягу на кожний кілограм повітря і зменшити масу двигуна і питому витрату палива 3 урахуванням підвищення степеня підвищення тиску в компресорі. Однак установлення теплообмінників у другому контурі погіршує його гідравлічні характеристики і збільшує тим самим питому витрату палива. Окрім цього, подача охолоджуючого повітря на нагріті поверхні може призвести до значних термічних напруг в матеріалі через нерівномірне поле температур по поверхні гарячих елементів турбіни [9-10].

Рідинне охолодження випотіванням було розроблено і випробувано в 30 -х роках минулого сто- ліття на турбінах професора В.В. Уварова. В наш час розробляються і способи охолодження з використанням рідинних металічних теплоносіїв (літія, калія, натрія). Застосування таких систем охолодження дає можливість забезпечити температуру газів $T_{\Gamma}^{*}$ до $2200-2$ 300К [11].

Проблема високих температур вирішується, 3 одного боку, підвищенням жароміцності і жаростійкості застосовуваних матеріалів, а з іншого боку, застосуванням жаростійких і теплозахисних покриттів i, нарешті, конструктивними методами створення спеціальних систем охолодження деталей. При підвищених температурах ресурс деталей значною мірою визначається досконалістю систем охолодження і живучістю захисних покриттів [12].

\section{Висновки}

Проведений аналіз шляхів підвищення температури газів перед турбіною сучасних газотурбінних двигунів літаків свідчить, що найбільш доцільним способом охолодження є транспіраційне 3 монокристалічними лопатками.

Це дозволяє забезпечити температуру газів перед турбіною $T_{\Gamma}^{*}$ до 2 200-2 300К. Перевагами цього способу охолодження $є$ простота реалізації та менші затрати. Матеріал даної статті може бути використаний для подальших досліджень ГТД.

\section{Список літератури}

1. Технологическое обеспечение эксплуатационных характеристик деталей ГТД. Лопатки компрессора и вентилятора: моногр. Часть 1 / А.В. Богуслаев, Ф.М. Муравченко, П.Д. Жеманюк, В.И. Колесников, В.К. Яценко, А.Я. Качан, Э.И. Цивирко, М.Р. Орлов, В.Е. Замковой, В.Ф. Мозговой, О.В. Рубель. - Запорожье: ОАО “Мотор Сич", 2003. $-396 \mathrm{c}$.

2. Технологическое обеспечение эксплуатационных характеристик деталей ГТД. Лопатки турбины: моногр. Часть 2 / А.В. Богуслаев, Ф.М. Муравченко, П.Д. Жеманюк, В.К. Яценко, А.Я. Качан, Э.И. Цивирко, С.Б. Беликов, М.Р. Орлов, В.Е. Замковой, В.Ф. Мозговой, О.В. Рубель. - Запорожье: ОАО “Мотор Сич”, 2003. - 420 с.

3. Прогрессивные технологии моделирования, оптимизации и интеллектуальной автоматизации этапов жизненного цикла авиационных двигателей: моногр. / А.В. Богуслаев, А.А. Олейник, А.А. Олейник, Д.В. Павленко, С.А. Субботин; под ред. Д.В. Павленко, С.А. Субботина. - Запорожье: ОАО “Мотор Сич”, 2009. - 468 с.

4. Магеррамова Л.А. Материалы рабочих лопаток и неразъемных роторов турбин / Л.А. Маггерамова, Ю.А Ножницкий // Машиностроение, Разд. IV. T. IV-21. Кн. 3. - Машиностроение, 2010. - С. 600-606.

5. Магеррамова Л.А. Влияние ориентации монокристалла на напряженно-деформированное состояние и прочность лопаток газовых турбин / Л.А. Маггерамова, Б.Е. Васильев // Вестник Московского авиационного института. - 2012. № 1. - С. 89-97.

6. Магеррамова Л.А. Расчетные методы увеличения ресурса рабочих лопаток авиационных газовых турбин / Л.А. Маггерамова // Вестник МАИ, 2013. - Т. 20, № 1. - С. 56-69.

7. Викулин А.В. Исследование теплообмена в системах охлаждения теплонапряженных конструкций / А.В. Викулин, Н.Л. Ярославцев, В.А Земляная // Теплоенергетика. - 2017. - С. 39-44. https://doi.org/10.1134/S0040363617010106.

8. Викулин А.В. Методология теплового проектирования охлаждаемых лопаток газовых турбин газотурбинных двигателей и газотурбинных установок / А.В. Викулин, Н.Л. Ярославцев, В.А. Чеснова // Научная мысль. - 2016. C. 86-105.

9. Барский И.А. Температура и термические напряжения в турбинных лопатках на неустановившихся режимах / И.А. Барський, Г.Г. Куватова // ИВУЗ. - 2005. - № 4. - С. 35-68.

10. Гуров В.И. Газотурбинные технологии / В.И. Гуров // ЦИАМ. - 2009. - Вип. 7. - С. 78.

11. Справочник по надёжности / пер. с англ.; под ред. Б.Е. Бердичевского. Т. 3. - М.: Мир, 1970. - 376 с.

12. Каблов Е.Н. Инновационные разработки ФГУП ВИАМ по реализации Стратегические направления развития материалов и технологий их переработки на период до 2030 года / Е.Н. Каблов // Авиационные материалы и технологии. - 2015. - № 1(34). - C. 3-33. https://doi.org/10.18577/2307-6046-2015-0-3-1-1. 


\section{References}

1. Bohuslaev, A.V., Muravchenko, F.M., Zhemaniuk, P.D., Kolesnykov, V.Y., Yatsenko, V.K., Kachan, A.Ia., Tsyvyrko, E.Y., Orlov, M.R., Zamkovoi, V.E., Mozghovoi, V.F. and Rubel, O.V. (2003), "Tekhnolohycheskoe obespechenye эkspluatatsyonnukh kharakterystyk detalei HTD. Lopatky kompressora y ventyliatora: monohrafia. Chast 1" [Technological support of operational characteristics of parts of the CCD. Compressor and fan blades: monograph. Part 1], OAO "Motor Sych", Zaporozhe, 396 p.

2. Bohuslaev, A.V., Muravchenko, F.M., Zhemaniuk, P.D., Yatsenko, V.K., Kachan, A.Ia., Tsyvyrko, E.Y., Belykov, S.B., Orlov, M.R., Zamkovoi, V.E., Mozghovoi, V.F. and Rubel, O.V. (2003), “Tekhnolohycheskoe obespechenye ekspluatatsyonnukh kharakterystyk detalei HTD. Lopatky turbynu: monohrafyia. Chast 2" [Technological support of operational characteristics of parts of the CCD. Turbine blades: monograph. Part 2], OAO "Motor Sych", Zaporozhe, $420 \mathrm{p}$.

3. Boguslaev, A.V., Olejnik, A.A., Olejnik, A.A., Pavlenko, D.V. and Subbotin, S.A. (2009), "Progressivnye tekhnologiimodelirovaniya, optimizacii i intellektual'noj avtomatizacii etapov zhiznennogo cikla aviacionnyh dvigatelej: monografiya" [Advanced technologies for modeling, optimization and intelligent automation of the stages of the life cycle of aircraft engines: a monograph], OAO "Motor Sich", Zaporozhe, $468 \mathrm{p}$.

4. Magerramova, L.A. and Nozhnitsky, Yu.A. (2010), "Materials of turbine blades and one-piecerotor" [Materials of rotor blades and fixed turbine rotors], Mashinostroenie, Enciklopedija, Vol. 4 (21), Book 3, pp. 600-606.

5. Magerramova, L.A. and Vasilyev, B.E. (2012), "Vlianie orientazii monokristala na napriagonno deformirovanue sostoynie na prohnosty lopatok gazovih" [The effect of single crystal orientation on the stress-strain state and strength of gas turbine blades], Vestnik MAI, No. 5, pp. 89-97.

6. Magerramova, L.A. (2013), "Rachetnie metodi yvelihenia resyrsa rabohih lopatoc aviatsuonnuh gavih tyrbine" [Calculation methods for increasing the resource of working blades of aircraft gas turbines ],Vestnik MAI, Vol. 20, No. 1, pp. 56-69.

7. Vikulin, A.V., Yaroslavtsev, N.L. and Zemlyanaya, V.A. (2017), "Icledovania teploobmena v sistemah ohlagdenia teplonaprigonnh constrycyi" [Study of heat transfer in cooling systems of heat-stressed structures], Teploenergetika, pp. 39-44. https://doi.org/10.1134/S0040363617010106.

8. Vikulin, A.V., Yaroslavtsev, N.L. and Chesnova, V.A. (2016), "Metodologia teplovogo proectirovania ohlagdaemih lopatoc gazovih turbin gazoturbinih dvigateley and gazoturbinnih ystanovocl" [Methodology of thermal design of cooled blades of gas turbines of gas turbine engines and gas turbine units], Scientific thought, No. 1, pp. 86-105.

9. Barskij, I.A. and Kuvatova, G.G. (2005), "Temperatura i termitheskie naprjagenija v turbinnyh lopatkah na neustanovivshihsja regimah" [Temperature and thermal stresses in turbine blades at unsteady conditions], IBUZ Mashinostroenie, No. 4, pp. 35-68.

10. Gurov, V.I. (2009),“Gazoturbine tehnologii” [Gas Turbine technologies], TSIAM, No. 2, pp. 78.

11. Berdychevskiy, B.E. (1970), “Spravochnyk po nadezhnosty” [Reliability Guide], Vol. 3, Myr, Moscow, 376 p.

12. Kablov, E.N. (2015), "Innovatciniy razrabotki of FSUE VIAM po realizatcii Strategiheskie napravlenia razvitia materialov and tihnologiy ih pererabotki na period do 2030 goda" [Innovative developments of FSUE VIAM for implementation Statistical directions for the development of materials and technologies for their processing for the period until 2030], Aviation materials and technologies, No. 1 (34), pp. 3-33. https://doi.org/10.18577/2307-6046-2015-0-3-1-1.

Надійшла до редколегії 04.02.2020 Схвалена до друку 10.03.2020

\section{Відомості про авторів:}

\section{Таврін Володимир Арнольдович}

кандидат технічних наук

доцент професор кафедри

Харківського національного університету

Повітряних Сил ім. І. Кожедуба,

Харків, Україна

https://orcid.org/0000-0001-9233-6246

\section{Колесник Єлизавета Вікторівна}

курсант

Харківського національного університету

Повітряних Сил ім. І. Кожедуба,

Харків, Україна

https://orcid.org/0000-0003-2620-4506

\section{Information about the authors:}

Volodymyr Tavrin

Candidate of Technical Sciences Associate Professor

Professor of the Department

of Ivan Kozhedub

Kharkiv National Air Force University,

Kharkiv, Ukraine

https://orcid.org/0000-0001-9233-6246

\author{
Liza Kolesnik \\ Cadet \\ of Ivan Kozhedub Kharkiv National \\ Air Force University, \\ Kharkiv, Ukraine \\ https://orcid.org/0000-0003-2620-4506
}




\title{
АНАЛИЗ ПУТЕЙ ПОВЫШЕНИЯ ТЕМПЕРАТУРЫ ГАЗОВ ПЕРЕД ТУРБИНОЙ СОВРЕМЕННЫХ ГАЗОТУРБИНЫХ ДВИГАТЕЛЕЙ САМОЛЕТОВ
}

\author{
В.А. Таврин, Е.В. Колесник
}

В статье проведен анализ особенностей работы газовой турбины как основного элемента газотурбинного двигателя (ГТД) в условиях воздействия высоких рабочих температур и давления, рассмотрена статистика характерных отказов и неисправностей газовых турбин, которые снижают надежность работы двигателей, и предложены альтернативные пути их преодоления. Рассмотрены пути повышения температуры газов перед турбиной современных ГТД и некоторые системы охлаждения сопловых аппаратов и рабочих лопаток турбин. Проанализированы направления повышения параметров рабочего процесса газовых турбин с иелью обеспечения безотказной работы авиационной техники в процессе эксплуатации.

Ключевые слова: эксплуатачия, технология прототипирования, монокристаллическое изготовление лопаток, термодиффузионный отжиг деталей, транспирационное охлаждение.

\section{ANALYSIS OF WAYS TO INCREASE GAS TEMPERATURE BEFORE THE TURBINE OF MODERN GAS TURBINE ENGINE AIRCRAFT}

\section{Tavrin, L. Kolesnik}

The article analyzes the peculiarities of gas turbine operation, as the main element of the gas turbine in conditions of high operating temperatures and pressure, examines the statistics of characteristic failures and malfunctions of gas turbines, which reduce the reliability of engines and proposed alternative ways to overcome them. Ways of raising the temperature of gases in front of the turbine of modern gas turbine and some systems of cooling of nozzle apparatus and working blades of turbines are considered. The directions of increasing the parameters of the workflow of gas turbines of high-temperature engines with the purpose of ensuring trouble-free operation of aviation equipment during operation are analyzed. Increased responsibility of the engine to ensure the safety, complexity of design and increase its cost, strict requirements for the combat readiness and survivability, expanding the combat use of aircraft is connected with the problem of creating the engine for the aircraft of the 5th generation, which would ensure the ability to operate at supersonic speeds with a maximum operating mode. The main trend in the development of engine designis a continuous increase in temperature in front of the turbine, in order to increase their thrust. Based on the results of analysis and statistical data of the gas turbine operation, ways to solve this problem are proposed. The main ways to increase the temperature of gases before the turbine include: production of blanks based on rapid prototyping, single-crystal manufacturing of blades, protection of surfaces from gas corrosion, oxidation and interaction of high operating temperatures through the use of modern methods of applying protective coatings, appropriate selection of the turbine cooling system, the use of turbo-injector engines. The main directions of technology for manufacturing gas turbine blades in the work make it possible to conduct a comparative analysis of aircraft cooling systems of different generations of leading countries in the world for the purpose of rational choice and efficiency of their application. Therefore, the need to ensure trouble-free operation of the turbine provides for a consistent finding of a reasonable compromise at all stages of the life cycle.

Keywords: operation, prototyping technology, single-crystal manufacturing of blades, thermal diffusion annealing of parts, transpiration cooling. 